\title{
ПОЛІТИЧНІ ПОГЛЯДИ ДВОРЯН БЕССАРАБСЬКОЇ ГУБЕРНІЇ НА ПОЧАТКУ ХХ СТОЛІТТЯ
}

Анотація: Одним із результатів першої російської револющії 1905-1907 рр. стала можливість офіщійно відкривати політичні організаиіі. Це сприяло тому, що на території багатьох адміністративно-територіальних одинищь Російської ілперії, котра була багатоетнічною країною, офіиійно стали відкриватися політичні організації різної ідеологічної спрямованості: національні, консервативні та ліберальні. Представники вищого стану держави теж були членами деяких політично спрямованих організацій.

у статті проведено дослідження політичних поглядів нобілів Бессарабської губернії на початку XX ст., ӥх зміни під час Першої світової війни. У публікації також розглянуто питання належності місцевих нобілів до політичних організацій, їх діяльність у них на початку XX ст. та під час Першої світової війни.

Ключові слова: Бессарабська губернія, дворяни, Перша світова війна, політичні погляди, румунофіли, чорносотенні організації

Початок ХX ст. став переломним моментом у соціально-економічному та політичному житті Російської імперії. У дворян, котрі були вищим суспільним станом та опорою російського престолу, на початку XX ст. змінилися соціальні норми та взаємовідношення 3 представниками царської влади, система політичних цінностей та уявлень. На початку ХХ ст. і напередодні Першої світової війни продовжували поставати політичні організації. Передумовою їх виникнення став розвиток національної свідомості, лібералізму серед дворян із-за економічних перетворень у самому стані, причина котрих була у капіталістичному розвитку країни.

Метою статті є дослідження політичних поглядів дворян Бессарабської губернії напередодні та під час Першої світової війни, їх участь у політичних організаціях.

Дослідження політичних поглядів дворян Бессарабської губернії є актуальною сьогодні темою, оскільки напередодні Першої світової війни відбувся новий поштовх розвитку національної та культурної свідомості у представників вищого стану губернії, що визначило подальший хід подій у Бессарабії.

Вивченням політичних поглядів мешканців Бессарабської губернії, а саме дослідженням національного молдавського руху з другої пол. XIX - початку XX ст. займалися такі вчені, як Г. Негру1 та О. Гром². С.М. Назарія ${ }^{3}$ вивчав еволюцію політичних

\footnotetext{
" Захарова Оксана Володимирівна - фахівець кафедри суднових енергетичних установок і систем Дунайського інституту НУ «ОМА» (м. Ізмаїл, Україна)

ORCID: https://orcid.org/0000-0001-9959-2699; e-mail: zaharova@dinuoma.com.ua

${ }^{1}$ Негру $\Gamma$. Национальное движение в Бессарабии во второй половине XIX - начале XX веков. URL: https://dacoromania.net
} 
поглядів інтелігенції та селян під час Першої світової війни у Бессарабській губернії. Діяльність відділів Союзу російського народу на території Бессарабської губернії та їх соціальний склад у своїх працях розглядав С.Г. Суляк ${ }^{4}$. Дослідженням участі дворян Бессарабської губернії у виборах до Державних дум займалася М. Башли додаткове дослідження політичних поглядів представників вищого стану Бессарабської губернії під час Першої світової війни, для того, щоб мати повністю чітке уявлення політичних поглядів всіх суспільних станів у цій адміністративно-територіальній одиниці.

Більшість суспільно-політичних сил, у склад котрих входили дворяни під час Першої світової війни, підтримували російську владу та входили до правих партій і чорносотенних організацій. Однак, дворяни доволі часто здійснювали сильний опір у реформаторській діяльності уряду, використовуючи при цьому свої позиції у Державній владі ${ }^{6}$

Більшість дворян Російської імперії підтримували правоконсервативний напрямок розвитку суспільства на початку XX ст. Вони виступали проти земського ліберального руху та намагалися захистити станові інтереси за допомогою Державної думи, у котрій їм під час війни належала більшість місць ${ }^{7}$. Праві партії на початку XX ст. можна вважати, у свою чергу, монархічними, оскільки вони обстоювали інтереси російського самодержавства: були за першість «руського» народу, об'єднуючи у цьому понятті російський, український і білоруський етноси ${ }^{8}$.

Під час Першої світової війни найчисельнішими право-монархічними організаціями на території Російської імперії були: Російське зібрання, Всеросійський Дубровинський союз російського народу, Союз російського народу, Російський народний союз ім. Михаїла Архангела і Вітчизняний патріотичний союз, котрий вийшов 3 останнього 9 . На початку XX ст. та напередодні Першої світової війни найчисельнішою організацією на території Бессарабської губернії був Союз російського народу ${ }^{10}$.

Серед дворян Бессарабської губернії членом правих монархічних організацій під час Першої світової війни був Г.В. Бутмі-де-Кацман ${ }^{11}$. На початку XX ст. він був активним

\footnotetext{
${ }^{2}$ Гром О.А. Молдавское национальное движение в Бессарабии в конце XIX - начале XX веков: дис... к. ист. н. Санкт-Петербург, 2017. 205 с.

${ }^{3}$ Назария С.М. Социально-экономическая и политическая эволюция Молдовы в период Первой мировой войны (1914-1918) // Русин. 2016. № 2 (44). C. 19-43. DOI: 10.17223/18572685/44/3

${ }^{4}$ Суляк С.Г. За веру, царя, отечество и землю крестьянам (о деятельности отделов Союза русского народа в Хотинском уезде Бессарабской губернии // Русин. 2018. № 54. C. 169-188. DOI: 10.17223/18572685/54/10

${ }^{5}$ Башли М. Дворяни Бессарабії - депутати Державних дум Російської імперії (1905-1917рp.)/ Теоретичні, методичні та практичні проблеми історії, філософії, соціології, політології, правознавства. Збірник наукових праць за матеріалами науково-практичної конференції. Ізмаїл: РВВ ІДГУ, 2017. С. 19-23.

${ }^{6}$ Бибин М.А. Совет объединенного дворянства в период Первой мировой войны: диссертация на соискание ученой степени доктора исторических наук. Саранск, 2002. С. 9.

${ }^{7}$ Ibid. C. 10.

${ }^{8}$ Стогов Д.И. Внешнеполитические ориентиры русских монархистов накануне и в годы Первой мировой войны // Гуманитарный научный журнал. 2014. № 1. С. 12.

${ }^{9}$ Стогов Д.И. Уставы и программы русских правых политических организаций периода Первой мировой войны: сравнительный анализ.

URL: https://lib.herzen.spb.ru/media/magazines/contents/1/130/stogov_130_19_31.pdf

${ }^{10}$ Суляк С.Г. За веру, царя, отечество и землю крестьянам... С. 169-188.

${ }^{11}$ Степанов А.Д., Иванов А.А. Черная сотня. Историческая энциклопедия 1900-1917 / Отв. ред. О.А. Платонов. Москва: Институт русской цивилизации, 2008. С. 79.
} 
громадських діячем і членом чорносотенної правої організації «Російське зібрання», а потім - Союзу російського народу. Напередодні Першої світової війни, з 1912 р. він продовжував активно займатися громадською діяльністю, тому його було обрано членом Головної палати Російського народного союзу ім. Михаїла Архангела (РНСМА), котрий заснував ще один представник вищого суспільного стану Бессарабської губернії В.М. Пуришкевич ${ }^{12}$, вийшовши зі складу Союзу російського народу.

Відмінною рисою РНСМА від інших правих монархічних організацій, за задумом його членів, мало стати сповіщення народу про діяльність правих членів Думи та забезпечення взаємозв'язку депутатів з народом і владою. Представники Головної палати РНСМА у своєму зверненні проголосили метою роботи організації економічне обєднання членів РНСМА для запобігання економічного пригноблення російської нації з боку євреїв. Мали на меті члени РНСМА також пробудження національної самосвідомості народних $\operatorname{Mac}^{13}$.

Голови чорносотенних організацій з 1906 р. були членами суспільно-політичної організації Об'єднаного дворянства та сформували їі ядро. На VII зїзді об'єднаного дворянства, котрий проходив 9-15 лютого 1911 р., на котрому обговорювалися питання перетворення середніх і вищих навчальних закладів, В.М. Пуришкевич запропонував провести реформи вищої школи: перестати приймати вільнослухачів, встановити строки перебування у вищих навчальних закладах, знищити предметну систему викладання, встановити контроль за студентами та проведення заходів по запобіганню їх зібрань i страйків. Саме студенти у Російській імперії найчастіше формували нові громадські організації. Також на цьому з'їзді дворяни вирішили, що не тільки у земських народних училищах, а й у національних школах викладання повинно проходити лише російською мовою ${ }^{14}$.

Втілювати у життя погляди щодо освіти В.М. Пуришкевич став в організації РНСМА. Головна палата РНСМА у 1912-1913 рр. організувала комісію для розбору підручників на книжковому ринку. Результати перевірки не задовольнили комісію. Пізніше члени РНСМА опублікували з цього приводу брошуру «Шкільна підготовка другої російської революції». Вона підштовхнула міністра народної просвіти Кассо, котрий також був бессарабським дворянином, займатися питаннями початкової школи ${ }^{15}$. І3-за циркуляра від 9 червня 1912 р., котрий був прийнятий Л.А. Кассо, відбулося відсторонення земств від керівництва бібліотеками, котрі були ними створені при земських школах. Циркуляр зобов'язував земство передати народні бібліотеки у повне розпорядження навчальних закладів, в яких вони були відкриті. До виходу цього циркуляру народні бібліотеки повністю належали земству і займалися забезпеченням бібліотек підручниками та книжками. Надалі бібліотеки повинні були працювати під контролем інспектора та директора народних училищ. Згідно циркуляру книжкові фонди народних бібліотек були підпорядковані дії міністерського каталогу. Земства за цими правилами могли лише жертвувати книжки у

\footnotetext{
${ }^{12}$ Ibid. C. $80,425$.

${ }^{13}$ Ibid. C. 454.

${ }^{14}$ Баринова Е.П. Российское дворянство в начале XX века: экономический статус и социокультурный облик. Москва: Российская политическая энциклопедия (РОСПЭН), 2008. С. 201.

${ }^{15}$ Степанов А.Д., Иванов А.А. Черная сотня... С. 459.
} 
бібліотеки ${ }^{16}$.е один циркуляр, котрий видало Міністерство народної освіти у цьому році, забороняв батькам визначати для вивчення їх дітьми рідної мови у школах і надавав таку можливість директорам шкіл ${ }^{17}$.

На початку XX ст. сформувався академічний рух, котрий сформувався на початку $\mathrm{XX}$ ст. й оформився інституціонально у вигляді Всеросійського академічного союзу (BАС $)^{18}$. B.M. Пуришкевич і члени РНСМА активно його підтримували ${ }^{19}$. Ця організація була професійним політичним об'єднанням діячів науки, професорів, студентів і викладачів вищих навчальних закладів. ВАС було відкрито у Петербурзі у 1905 р. Члени ВАС виступали за відсутність політики у стінах університету, за спокійне протікання академічного життя, за боротьбу зі студентськими страйками, за підняття гідності та честі студентського мундиру, за підняття студентського благополуччя за допомогою створення бюро праці та каси взаємодопомоги.

Праві монархічні студентські організації часто отримували фінансування та підтримку від правих чорносотенних організацій. В.М.Пуришкевич займався фінансуванням академічних студентських організацій. Він не безуспішно у 1908 p. намагався підпорядкувати собі студентські академічні організації, котрі вже працювали при інших правих партіях. Російський жіночий гурток учнів м. Москви, котрий було організовано при Російському монархічному зібранні перейшов до РНСМА i В.М. Пуришкевич у ньому отримав звання почесного члена. 31908 р. по 1912 р. РНСМА за рахунок власних коштів виділив академічній корпоращії студентів Гірничого інституту 300 руб., академістам Петербурзького університету - 225 руб., Лісового інституту 125 руб., Гірського та Політехнічного інститутів - по 75 руб. Загальна сума за 4 роки становила 11574 руб. 57 коп. ${ }^{20}$

У 1912 р. В.М. Пуришкевич намагався підкорити собі весь академічний рух, ввівши до складу Союзу російських студентів, Російської академічної корпорації та Всеросійського національного студентського союзу своїх ставлеників - «Палатників». Один з них отримав від нього 800 руб. «для роздачі нужденним студентам». У 1913 р. всіх «Палатників» виключили із Союзу російських студентів, а в лютому 1914 р. виникла Нова російська академічна корпорація, яка об’єднала супротивників В.М. Пуришкевича, в якій налічувалося 50 осіб. у Корпорації, що зберегла вірність голові РНСМА, залишилося всього 12-13 осіб ${ }^{21}$.

у 1912-1913 pр. ще одним головним питанням, яким займався РНСМА, було розслідування обставин убивства у Києві хлопчика А. Ющинського та процес по обвинуваченню єврея Менделя Бейліса в організації ритуального вбивства ${ }^{22}$.

\footnotetext{
${ }^{16}$ Рубанова Т.Д. Правовое положение земских народных библиотек в 1905-1917 гг. // Вестник Челябинской государственной академии культуры и искусств. 2010. № 4 (24). С. 8.

${ }^{17}$ Бардаш О.Д. Російське самодержавство та суспільно-культурне життя в Україні на початку XX століття (1900-1917 рр.). Київ: Український пріоритет, 2011. С. 128.

${ }^{18}$ Ковтуненко М.К. Движение правого академизма в Императорском Новороссийском Университете в начале XX в. // Электронный журнал «Вестник МГОУ». 2014. № 1. URL: https://evestnik-mgou.ru/ru/Articles/Doc/539

${ }^{19}$ Степанов А.Д., Иванов А.А. Черная сотня... С. 459.

${ }^{20}$ Омельянчук И.В. Академисты. URL: http://www.stolypin.ru/proekty-fonda/entsiklopediya-petr-arkadevichstolypin/?ELEMENT_ID=345

${ }^{21}$ Омельянчук И.В. Академисты...

${ }^{22}$ Степпанов А.Д., Иванов А.А. Черная сотня... С. 459.
} 
В.М. Пуришкевич зробив все, що зміг для того, щоб довести цю справу до суду. У 1912 p. були опубліковані фото 3 тіла та сорочки вбитого хлопця, котрі належали B.М. Пуришкевичу. Всі отримані від продажу фото гроші були ним передані до фонду імені А. Ющинського. Перед початком суду по цій справі Пуришкевич видав брошуру католицького священика І. Пранайтиса «Таємниця крові у іудеїв». У 1913 р. лідер РНСМА розіслав таємний циркуляр із закликом підтримати мати померлого хлопчика й осіб, котрі ій допомагають ${ }^{23}$.

у 1914 р. був затверджений статут ще однієї правої організації «Філаретівське товариство народної освіти» (ФТНО), котру заснував В.М. Пуришкевич для виконання охоронних заходів освіти у початковій школі ${ }^{24}$. Під час Першої світової війни ФТНО займалося наданням допомоги родинам вчителів, призваних до військових рядів діючої армії та постраждалим на фронтах війни ${ }^{25}$.

На початку Першої світової війни, відкинувши всі політичні суперечки, B.М. Пуришкевич поїхав на фронт у складі санітарного загону А.І. Гучкова. Згодом він склав власний загін, котрим він керував до кінця війни, а тому відійшов від активної діяльності у створених ним до війни організаціях. Російським царем загін В.М. Пуришкевича був визнаний одним 3 кращих ${ }^{26}$. Його загін займався облаштуванням санітарного потягу разом із Голіциним.

Під час Першої світової війни, перебуваючи на фронті, у зв'язку з тим, що Німеччина була ворогом, В.М. Пуришкевич відмовився від германофільства. У цей час його погляди все більше розходилися із монархістами. Він також виступав проти їх зїздів, заявляючи при цьому, що, на його думку, під час війни мають місце бути лише зїзди спрямовані на надання допомоги армії.

3 другої половини 1915 р. Пуришкевич дозволяв собі публічні виступи із критикою уряду. У 1916 р. він негативно висловлювався про німщів, котрі проживали на території Російської імперії, не дивлячись на те, що серед них теж було багато монархістів. Через це на початку 1916 р., у зв'язку із його виступом проти німщів, відбулося обговорення поведінки та поглядів В.М. Пуришкевича у Державній думі на зборах Ради монархічних зїздів. Представниками деяких місцевих організацій РНСМА було запропоновано позбавити його посади голови РНСМА, що сприяло остаточній зміні політичних поглядів Пуришкевича та його виходу з монархічного руху, але він все одно продовжував називати себе монархістом ${ }^{27}$.

Більшість чорносотенних організацій на початку 1917 р. перестали існувати. Однією 3 причин стали чвари всередині організацій, що започаткувало занепад їх діяльності.

Ще одним напрямком політичних поглядів дворян Бессарабської губернії було румунофільство. Стан вивчення молдавської мови дітьми дворян Бессарабської губернії та питання культурного розвитку, можливість вести засідання у державних організаціях молдавською мовою стало причинами формування національного руху Бессарабської губернії. До цього руху передусім входили представники місцевої еліти та інтелігенції.

\footnotetext{
${ }^{23}$ Ibid. C. 426.

${ }^{24}$ Ibid. C. 427.

${ }^{25}$ Ibid. C. 129.

${ }^{26}$ Ibid. C. 427.

${ }^{27}$ Степпанов А.Д., Иванов А.А. Черная сотня... С. 427.
} 
Дворяни Бессарабської губернії почали турбуватися про стан вивчення молдавської мови їх дітьми з 1839 р., але у місцевої влади не було достатньо грошей для виплати утримання повітовим вчителям, тому знання природної мови для молдавської етнічної групи серед підростаючого покоління у губернії були незадовільними. 5 вересня 1841 p. обласний предводитель Бессарабського дворянства Стурдза надіслав Бессарабському військовому губернатору П.І. Федорову звернення № 366 із проханням призначити вчителів молдавської мови до повітових училищ I та II розрядів і виписати з Молдавії та Валахії необхідну кількість навчальних підручників для забезпечення вивчення курсу молдавської мови. Обласний предводитель дворянства скаржився у своєму звернені, що діти дворян не знають ані молдавської, ані російської мови на необхідному рівні для ведення справ. У тому випадку, якщо кошти для задоволення цього питання представники обласної влади не знайдуть, дворяни пропонували виплачувати кошти для виплати заробітних плат і купівлю навчальних матеріалів 3 громадських податків, котрі сплачували поміщики ${ }^{28}$.

У 60-х pp. XIX ст. представники вищого стану Бессарабської губернії: Кассо, Крісті, Казимир, котрі входили до складу націоналістичного угрупування молдавських бояр ${ }^{29}$, періодично підіймали питання на дворянських зборах про ведення церковних служб, отримання освіти у навчальних закладах і можливості проведення публічних виступів у губернських земських і дворянських зборах, а також право вести судові засідання молдавською мовою ${ }^{30}$.

Царський уряд, розглянувши ці питання, ввів посаду перекладача молдавської мови у судове діловодство та не дав дозволу вести засідання, або робити доповіді молдавською мовою на дворянських і земських зборах ${ }^{31}$. Питання, рішення по котрих не задовольнили представників місцевої еліти, стали причиною появи національного руху на території Бессарабської губернії, котрий остаточно сформувався у вересні 1905 р. із заснуванням у Кишиневі Бессарабського Молдавського товариства на чолі з П.Дическул, котрий був спадковим дворянином Бессарабської губернії.

Націоналістичні ідеї представників вищого стану з молдавської етнічної групи на території губернії поширювалися у місцевих газетах, під час спілкування з мешканцями губернії та проведення приватних уроків вчителями, котрі входили до молдавського національного руху ${ }^{32}$.

У 1906 р. почав виходити журнал «Бессарабія», котрий видавався у Женеві. Серед працівників редакції журналу був дворянин В. Кужба, котрий через 4 місяці своєї роботи був висланий представниками місцевої влади до Румунського королівства. Питання, котрі підіймали представники національного руху Бессарабської губернії сприймалися царським урядом Російсько імперії як румунофільські настрої ${ }^{33}$.

Всі питання, що розглядали члени національного молдавського руху Бессарабської

\footnotetext{
${ }^{28}$ Національний архів республіки Молдова. Ф.2. Оп. I (1841). Д. 1316. Переписка областного предводителя Бессарабского дворянства с Бессарабским военным губернатором. Л. 25-29.

${ }^{29}$ Негру Г. Национальное движение в Бессарабии...

${ }^{30}$ Гром O.A. Молдавское национальное движение в Бессарабии в конце XIX - начале XX веков: дис... канд. ист. н. Санкт-Петербург, 2017. С. 163.

${ }^{31}$ Негру Г. Национальное движение в Бессарабии...

${ }^{32}$ Гром О.А. Молдавское национальное движение в Бессарабии... С. 167.

${ }^{33}$ Негру Г. Национальное движение в Бессарабии...
} 
губернії почали виходити на шпальтах газети «Молдованул» з січня 1907 р., але їі закрили у листопаді 1908 p. $^{34}$

Повторний поштовх розвитку національного руху на території Бессарабської губернії відбувся напередодні Першої світової війни у квітні 1913 р., котрий був повязаний із початком виходу газети «Голос Бессарабії.

Газета «Голос Бессарабії» пропагувала культурний вірнопідданський націоналізм і виправдовувала діяльність царської влади щодо відсутності у місцевих жителів Бессарабської губернії «національної культури» у представників молдавської етнічної групи. Однак на іï сторінках були надруковані статті присвячені проблемі русифікації молдован ${ }^{35}$. За словами головного редактора газети Константинеску, ця проблема крилася саме у молдаванах. Селяни скептично ставилися до отримання освіти їх дітьми і мова, якою велося викладання, була їм байдужа, тому відкривати додаткові класи з румунською мовою навчання було недоцільно ${ }^{36}$.

Його позицію можна пояснити тим фактом, що восени 1910 р. на розгляд Державної думи було винесено законопроект про загальну середню освіту і в ньому були примітки у статті 9: «у місцевостях з іномовним населенням дозволяється, за згодою повітової чи міської училищної ради, викладання місцевих мов для бажаючих» і у статті16 «...у місцевостях, де діти, що вступають до училища, не говорять російською мовою, допускається при навчанні користуватися природною мовою, якою говорять учні в сім'ї, у перший, а при необхідності й у другий рік навчання. 3 початком третього року викладання всіх предметів, крім Закону Божого і рідної мови, матиме місце російською мовою». По причині поправок, внесених у ці статті, членом Державної Ради Д. Піхно малоруське наріччя не повинно було вважатися іномовним у місцевостях з малоруським і білоруським населенням, викладання всіх предметів у таких адміністративно-територіальних одиницях мало проходити російською мовою ${ }^{37}$. Це означало, що на території Бессарабської губернії неможливо було відкрити українську народницьку школу, але була можливість при бажанні відкрити таку молдавську школу, котра не проіснувала б довго. Вже у травні 1913 р. Міністерство народної освіти надало Державній думі на розгляд законопроект, котрий стосувався кошторису для розвитку народної освіти на 1914 р. Одним із пунктів у цьому документі заборонялося викладання місцевою неросійською мовою, починаючи 3 початкової школи ${ }^{38}$.

Кількість передплатників газети «Голос Бессарабії у 1914 р. становила 600 осіб, але більшу їх кількість складали люди, котрі не оплатили шестимісячну або річну підписку. Передплачували цю газету дворяни, священики, вчителі та військові ${ }^{39}$. У молдавському націоналістичному дискурсі брали участь лише $0,1 \%$ населення Бессарабської губернії. За доносами полковника жандармерії Нордберга, газета «Голос Бессарабії» отримувала фінансування від Румунського королівства ${ }^{40}$.

\footnotetext{
${ }^{34}$ Гром О.А. Молдавское национальное движение в Бессарабии... С. 160.

${ }^{35}$ Ibid. C. 169.

${ }^{36}$ Ibid. C. 165.

${ }^{37}$ Бардаш О.Д. Російське самодержавство... С. 125-126.

${ }^{38}$ Бардаш О.Д. Російське самодержавство... С. 127.

${ }^{39}$ Гром О.А. Молдавское национальное движение в Бессарабии... С. 166.

${ }^{40}$ Ibid. C. 167.
} 
Після докладу, за розпорядженням віце-губернатора Бессарабської губернії № 48 від 23 березня 1914 р., номер газети «Голос Бессарабії» був конфіскований. Останній номер цієї газети вийшов 6 серпня 1914 р. Причиною цього був постійний нагляд за редактором газети Константинеску з боку місцевих жандармів ${ }^{41}$.

У 1914 р. стали виходити більш національно спрямовані журнал та газета «Кувинт Молдовенеск». Її головним редактором був спадковий дворянин Бессарабської губернії Олександрі, котрий за даними доносу полковника Нодберга знаходився у близьких родинних стосунках із заможними поміщиками Бессарабської губернії: Леонардом, Феодосіу та Дическулом і став ярим молдавським патріотом, прибічником возз'єднання Бессарабії з Румунією. Він став прибічником румунофільських поглядів після повернення із Румунії у 1914 p. $^{42}$

Навколо редакції «Кувинт Молдовенеск» згрупувалися особливо завзяті румунофіли: помічник присяжного повіреного Семен Георгієв Мурафа, співробітник газети «Бессарабське життя», спадковий дворянин Бессарабської губернії Г.В.Стирче та П.М. Халіпа ${ }^{43}$. Під час Першої світової війни до складу національного руху входили також дворяни Чолаку та Чухурян ${ }^{44}$.

Видання «Кувинт Молдовенеск» також отримував фінансування від румунської еліти. Начальник жандармського управління полковник Нодберг у своєму доносі доповідав про те, що на початку 1914 р. видання «Кувинт Молдовенеск» отримало кошти від Ліги за культурне об'єднання всіх румун у розмірі 2000 франків. Крім цього, видавці отримували матеріальну допомогу від Оргіївського, Бендерського та Кишинівського земств. Виділяв кошти на це видання також бессарабський дворянин В. Строєску, котрий був румунським філантропом ${ }^{45}$.

Газета «Кувинт Молдовенеск» друкувалася молдавською мовою46. у своїй доповіді начальник Бессарабського губернського жандармського управління 31 жовтня 1915 р. наступним чином охарактеризував газету: “Кувинт Молдовенеск” виходить молдавською мовою, котра має яскраво «націоналістичний» напрямок з сепаратистською тенденцією. Субсидується деякими повітовими земствами шляхом підписки 300 номерів, а також субсидується з Румунії. Поширюється в селі безкоштовно. Друкується у кількості до 6000 номерів, охоче виписується та поширюється духовенством, серед яких багато “націоналістів" "

За свідченнями румунського активіста О. Норуа видання «Кувинт Молдовенеск» були

\footnotetext{
${ }^{41}$ Ibid. C. 174.

${ }^{42}$ Сведения №193 по Юлдавскому национальному движению, полученные 30 числа января месяца 1914 года. URL: https://dacoromania.net/article/документы-по-национальному-движению-в-бессарабии-1812-1917

${ }^{43}$ Ibidem.

${ }^{44}$ Доклад № 9300 полковника Нодберга Начальнику Бессарабского Губернского Жандармского Управления 18 Мая 1915 г. URL: https://dacoromania.net/article/документы-по-национальному-движению-в-бессарабии1812-1917

${ }^{45}$ Гром О.А. Молдавское национальное движение в Бессарабии... С. 175.

${ }^{46}$ Иллюстрированный адрес-календарь Бессарабской губернии 1916г. / Бессарабский губернский статистический комитет / под ред. Топеро В.А. Кишинев, 1916. 538 с.

${ }^{47}$ Доклад Начальника Бессарабского Губернского Жандармского Управления 31 октября 1915 г. Кишинев. URL: https://dacoromania.net/article/документы-по-национальному-движению-в-бессарабии-1812-1917
} 
доволі популярними і мали тираж у 1914 р. по 2000 журналів і газет. У 1915 р. тираж газети становив 6 000-10 000 примірників. Ці видання були єдиними, котрі виходили регулярно аж до революції 1917 р. У статтях, котрі виходили у цих виданнях, підіймалися питання про місце молдавської мови в освіті та веденні проповідей молдавською мовою, необхідністю «культурної роботи» 3 місцевими жителями з молдавської етнічної групи, котрі втратили свою національну ідентичність ${ }^{48}$.

Отже, на території Бессарабської губернії у представників вищого стану були різні політичні погляди. Серед них були представники чорносотенного монархізму та молдавського націоналізму.

Монархісти, на прикладі діяльності РНСМА, активно підтримували владу Російської імперії на чолі з царем. Вони були оплотом царської влади, передусім у питаннях пов'язаних з освітою. Головою однієї з найбільших правих організацій - Союзу російського народу ім. Михаїла Архангела був депутат Верховної ради, дворянин Бессарабської губернії В.М. Пуришкевич. До правих політичних сил серед представників вищого стану Бессарабської губернії відносився також Бутмі-де-Кацман.

B.М. Пуришкевич був найвпливовішою постаттю у вищому стані Російської імперії серед монархістів Бессарабської губернії. Його політичні погляди змінилися під час Першої світової війни. Знаючи реальний хід подій, перебуваючи на фронті під час війни, B.М. Пуришкевич змінив свої погляди та ставлення до царської влади Російської імперії, а це свідчить про зміну політичної культури. Війна з Німеччиною стала причиною його відмови від германофільства, що викликало незадоволення й обурення серед монархістів, котрі виступили за зняття його з посади голови заснованого ним РНСМА.

Міністр освіти Л.А. Кассо мав суперечливі політичні погляди. 3 одного боку, він виступав за вивчення молдавської мови дітьми у школах Бессарабської губернії, а з іншого підтримував російську владу у питанні проведення всіх уроків російською мовою, що говорить про його молдавські національні погляди напередодні Першої світової війни. Він випустив указ про відчуження бібліотек від земських органів місцевого самоврядування, тому що гласні мали ліберальні погляди та закупали до бібліотек, на думку царського уряду, небезпечні для влади книжки, котрі читали не тільки діти, а й їх батьки, що могло спричинити революцію.

Русифікація місцевого населення Бессарабської губернії та відсутність прийнятих рішень, котрі задовольнили б інтелігенцію та місцеву еліту у питаннях пов'язаних із можливістю користуватися молдавською мовою у державних установах, стали причиною формування національного руху. Він у Бессарабській губернії офіційно сформувався у 1905 р. і тривав до 1908 р., а потім активізувався знову напередодні Першої світової війни за допомогою румунських націоналістів, але не отримав широкого поширення серед місцевих жителів, оскільки Бессарабська губернія була поліетнічною територією.

Націоналістично спрямованими були місцеві дворяни та інтелігенція з молдавської етнічної групи, котрі контактували 3 представники румунської буржуазії. Еліта Румунії бачила у національному русі можливість для приєднання Бессарабської губернії до Румунського королівства, а тому надавала фінансову підтримку друку націоналістично

\footnotetext{
${ }^{48}$ Гром О.А. Молдавское национальное движение в Бессарабии... С. 176.
} 
спрямованих видань. Єдиним виданням, котре на своїх сторінках друкувала статті національного змісту під час Першої світової війни було «Кувинт Молдовенеск».

\section{Oksana Zakharova}

\section{Political views of the Bessarabian nobility in the early XX century}

Abstract: One of the results of the first Russian revolution of 1905-1907 was the opportunity to formally establish political organizations. This contributed to the activation of national movements and the formation of various political organizations in many administrative-territorial units of the Russian Empire.

The article considers the participation and activities of the Bessarabian nobles in the national movement in the early XX century and during the First World War. The publication examines which monarchical political organizations included representatives of the highest status of the province, their political activities, and views.

The research found that in the territory of Bessarabia province a political national movement was formed in the Moldovan ethnic group, which included representatives of the highest social class. Among the participants in the Moldovan national movement were members of the Alexandri family, G.V. Styrche, Stroesku, Chukhuryan, Cholaku. The Minister of Education L.A. Kasso also had nationalist views. This movement received support from local landowners, as well as from the Orhiiv, Bender, and Chisinau zemstvos, and representatives of the Romanian authorities. Supporting the national movement in the Moldovan ethnic group, the representatives of royal Romania tried to create favorable conditions for the accession of Bessarabia. They pursued their interests, which led to the Bessarabian question during the First World War. In addition to representatives of the national movement, the Black Hundreds were also among the nobles of the Bessarabian province. the most famous of them was V.M. Purishkevich, who left the Union of the Russian people, founded the Russian People's Union named after Mikhail the Archangel, who, being at the front, changed his political views during the war and ceased to be a monarchist.

Keywords: Bessarabian province, nobles, World War I, political views, Moldovan national movement, Black Hundreds 